\title{
Lack of involvement of nucleotide excision repair gene polymorphisms in colorectal cancer
}

\author{
R Mort', L Mo', C McEwan' and DW Melton*,I \\ 'Sir Alastair Currie Cancer Research UK Laboratories, Molecular Medicine Centre, University of Edinburgh, Western General Hospital, Crewe Road, \\ Edinburgh EH4 2XU, UK
}

\begin{abstract}
DNA repair has an essential role in protecting the genome from damage by endogenous and environmental agents. Polymorphisms in DNA repair genes and differences in repair capacity between individuals have been widely documented. For colorectal cancer, the loss of mismatch repair gene activity is a key genetic determinant. Nucleotide excision repair (NER), recombination repair (RR) and base excision repair (BER) pathways have critical roles in protection against other cancers, and we wished to investigate their role in colorectal cancer. We have compared the frequency of polymorphisms in the NER genes, XPD, XPF, XPG, ERCCI; in the BER gene, $X R C C l$; and in the RR gene, $X R C C 3$; in colorectal cancer patients and in a control group. No significant associations were found for any of the NER gene polymorphisms or for the XRCCI polymorphism. The C allele (position 18067) of the XRCC3 gene was weakly but significantly associated with colorectal cancer (odds ratio 1.52, 95\% confidence interval 1.04-2.22, $P=0.03$ ). For all patients who were heterozygous for any of the repair genes studied, tumour tissue was investigated for loss of heterozygosity ( $\mathrm{LOH}$ ). Only one example of $\mathrm{LOH}$ was found for all the genes examined. From the association and LOH data, we conclude that these genes do not have an important role in protection against colorectal carcinogenesis. British Journal of Cancer (2003) 89, 333-337. doi:I0.1038/sj.bjc.660 I06I www.bjcancer.com (c) 2003 Cancer Research UK
\end{abstract}

Keywords: DNA damage; DNA repair; loss of heterozygosity; xeroderma pigmentosum

Several complementary DNA repair mechanisms have evolved to protect the genome from DNA damage caused by endogenous or environmental agents, which could lead to mutations and carcinogenesis (Friedberg, 2001). DNA repair capacity varies between individuals in the general population (for a review, see Berwick and Vineis, 2000). An increasing number of DNA repair gene polymorphisms are being described and their involvement in carcinogenesis is being investigated. For colorectal cancer, the importance of mutations in mismatch repair (MMR) genes has been extensively documented. MMR gene defects account for $15 \%$ of sporadic colorectal cancer, and germline mutations in MMR genes are the cause of hereditary nonpolyposis colon cancer (for a review, see Jiricny and Nystrom-Lahti, 2000). The role of additional low-penetrance genes in colorectal cancer susceptibility has been recently reviewed (de Jong et al, 2002). We wished to investigate the hypothesis that alterations in other DNA repair pathways were also important genetic determinants of colorectal carcinogenesis.

The nucleotide excision repair (NER) pathway deals with UV light-induced DNA damage (for a review, see Wood, 1997). In the inherited disorder, xeroderma pigmentosum, NER deficiency results in a 1000-fold increased incidence of skin cancer, but also a 20-fold increase in internal tumours (Friedberg et al, 1995), indicating that NER is also important in the repair of endogenous DNA damage. Indeed, the digestive tract contains materials such as

*Correspondence: Prof DW Melton; E-mail: david.melton@ed.ac.uk Received 23 December 2002; revised 3I March 2003; accepted 24 April 2003 lipid peroxidation by-products that can react with DNA to generate bulky adducts that are recognised by NER (Friedberg et al, 1995). Amino-acid variants in NER genes are common in the general population (Shen et al, 1998) and some, such as the XPD exon 23 polymorphism, have been associated with reduced DNA repair capacity (Lunn et al, 2000; Qiao et al, 2002). We have reported a significant association between polymorphisms in exons 6,22 and 23 of the XPD gene and melanoma in patients under 50 (Tomescu et al, 2001). Significant association between NER gene polymorphisms and other cancers, but not colorectal, have also been reported: glioma (Chen et al, 2000); lung (Chen et al, 2002; Park et al, 2002); squamous cell carcinoma of the head and neck (SCCHN; Sturgis et al, 2002).

The XRCC1 gene is involved in the repair of single-strand DNA breaks and in base excision repair (BER) of damaged bases caused by endogenous and exogenous oxidants, including tobacco smoke. XRCC1 polymorphisms have been associated with SCCHN (Sturgis et al, 1999), pancreatic adenocarcinoma (Duell et al, 2002), lung cancer (Chen et al, 2002) and bladder cancer (Stern et al, 2002). There is also a single report of a significant association with colorectal cancer (reviewed by de Jong et al, 2002). The XRCC3 gene, a paralogue of RAD51, is involved in recombination repair (RR) and is required for genome stability (Griffin et al, 2000). XRCC3 polymorphisms have been associated with melanoma (Winsey et al, 2000), bladder cancer (Matullo et al, 2001a; Stern et al, 2002) and SCCHN (Shen et al, 2002).

Loss of heterozygosity ( $\mathrm{LOH}$ ) of tumour suppressor genes, such as p53, APC and BRCA1, is an important step in carcinogenesis. LOH for NER genes has been reported as a common occurrence in a range of carcinomas (Takebayashi et al, 2001), and we also 
wished to study LOH of NER genes in our colorectal cancer samples.

In this study, we have compared the frequency of polymorphisms in the NER genes (XPD, XPF, XPG, ERCC1), and in XRCC1 and $X R C C 3$ in colorectal cancer patients and a control group. Furthermore, for patients heterozygous at any of these loci, we have looked for $\mathrm{LOH}$ in a biopsy of tumour tissue.

\section{MATERIALS AND METHODS}

\section{Subjects}

Subjects were colorectal cancer patients (mean age 69 years) attending the Western General Hospital, Edinburgh, UK. Biopsy material, from cancerous and adjacent noncancerous tissue, was collected between 1994 and 1997 by Professor Andrew Wyllie for histology and DNA extraction. At the same time, control blood samples were selected entirely at random from donors to the Scottish National Blood Transfusion Service (mean age of donors is 42 years), and DNA was extracted as described (Tomescu et al, 2001).

\section{PCR and RFLP assays}

The polymorphisms studied are shown in Table 1. All, apart from the XPG exon 15 polymorphism (Emmert et al, 2001), were originally described by Shen et al (1998). Polymorphisms were chosen for study because, in each case, the variant allele was common and the single-nucleotide change resulted in the gain, or loss, of a restriction site so that the polymorphism could be easily typed by PCR and RFLP analysis. In addition, significant associations between some of these polymorphisms and cancer have previously been reported. Details of the RFLPs are shown in Table 1. Details of the PCR products, primers and cycle conditions used are shown in Table 2. Genomic DNA $(\sim 100 \mathrm{ng})$ was amplified in a $50 \mu \mathrm{l}$ reaction volume containing $300 \mathrm{ng}$ of each primer and 2.5 U Taq DNA polymerase (Promega, UK) in $50 \mathrm{~mm}$ $\mathrm{KCl}, 1.5 \mathrm{~mm} \mathrm{MgCl}_{2}, 10 \mathrm{~mm}$ Tris- $\mathrm{HCl} \mathrm{pH} 8.3,0.45 \%$ Triton X-100, $0.45 \%$ Tween 20, $0.4 \mathrm{~mm} \mathrm{Na}_{2}$ EDTA, $0.1 \mathrm{~mm}$ dNTPs.

\section{Statistical analysis}

We first investigated whether the observed genotype distributions at each locus were consistent with a Hardy-Weinberg equilibrium. Having confirmed that this was the case, we assumed that alleles were independent at each locus, and compared allele counts among cases and controls. A $\chi^{2}$-test with Yates' correction was used to give a conservative test for the significance of any association between a polymorphism and colorectal cancer.

\section{RESULTS}

Initially, we set out to genotype a minimum of 40 patient and control samples for the eight DNA repair gene RFLPs shown in Table 1. Where less genotypes than this are reported for each sample group, it is because some genotyping reactions failed. In the one instance (XRCC3 exon 7), where a significant association was found during this first round of genotyping, additional patient and control samples were then genotyped to increase the power of the statistical analysis. All the genotyping data obtained from the patient and control samples analysed are presented below. The patterns obtained for XPF exon 11, XPG exon 15, XRCC1 exon 17 and $X R C C 3$ exon 7 are illustrated in Figure 1. The patterns for the $X P D$ (exons 6, 22 and 23) and ERCC1 exon 4 polymorphisms have been described previously (Tomescu et al, 2001). For each polymorphism investigated in the control and patient groups, the observed genotype distributions were compared with the expected frequencies under the Hardy-Weinberg equilibrium. In each case, there were no significant deviations from the expected values. We therefore assumed independence of alleles at these loci and compared allele counts, rather than genotypes, in patient and control groups because of the resulting increased power of the statistical analysis.

Table I Details of RFLPs studied and fragment sizes

\begin{tabular}{|c|c|c|c|c|c|}
\hline Gene/exon & Enzyme & Polymorphism & Position $^{a}$ & Genotype & Fragment sizes (bp) \\
\hline$X P D$ exon 6 & Hinfl & $C$ to $A$ & 22541 & $\begin{array}{l}\text { CC } \\
\text { CA } \\
\text { AA }\end{array}$ & $\begin{array}{c}288 \text { (no cut) } \\
288+206+82 \\
206+82\end{array}$ \\
\hline XPD exon 22 & Fokl & $C$ to $T$ & 35326 & $\begin{array}{l}\text { CC } \\
\text { CT } \\
\pi T\end{array}$ & $\begin{array}{c}229 \text { (no cut) } \\
229+135+94 \\
135+94\end{array}$ \\
\hline XPD exon 23 & Pstl & A to $C$ & 35931 & $\begin{array}{l}\mathrm{AA} \\
\mathrm{AC} \\
\mathrm{CC}\end{array}$ & $\begin{array}{c}234+110 \\
234+172+110+62 \\
172+110+62\end{array}$ \\
\hline$E R C C I$ exon 4 & BsrDI & $G$ to $A$ & 19007 & $\begin{array}{l}\text { GG } \\
\text { GA } \\
\mathrm{AA}\end{array}$ & $\begin{array}{c}252 \text { (no cut) } \\
252+179+73 \\
179+73\end{array}$ \\
\hline$X P G$ exon 15 & Nlalll & $G$ to $C$ & $\begin{array}{c}3507 \\
\text { (cDNA) }\end{array}$ & $\begin{array}{l}\text { GG } \\
G C \\
C C\end{array}$ & $\begin{array}{c}27 I \text { (no cut) } \\
27 I+227+44 \\
227+44\end{array}$ \\
\hline XPF exon II & AlwNI & $T$ to $C$ & 30028 & $\begin{array}{l}\text { TT } \\
\text { TC } \\
\text { CC }\end{array}$ & $\begin{array}{c}442+267 \\
709+442+267 \\
709 \text { (no cut) }\end{array}$ \\
\hline$X R C C I$ exon 17 & Stul & $G$ to $A$ & 36189 & $\begin{array}{l}\text { GG } \\
\text { GA } \\
\mathrm{AA}\end{array}$ & $\begin{array}{c}343+158 \\
501+343+158 \\
501 \text { (no cut) }\end{array}$ \\
\hline$X R C C 3$ exon 7 & Nlalll & $C$ to $T$ & 18067 & $\begin{array}{l}C C \\
C T \\
T T\end{array}$ & $\begin{array}{c}346 \text { (no cut) } \\
346+242+104 \\
242+104\end{array}$ \\
\hline
\end{tabular}

a Nucleotide positions are from the GenBank entries: XPD, L47234; ERCCI, M63796; XPG, NM_000I23; XPF, L76568; XRCCI, L34079; XRCC3, AF037222. 
Table 2 Details of PCR products for polymorphism analysis

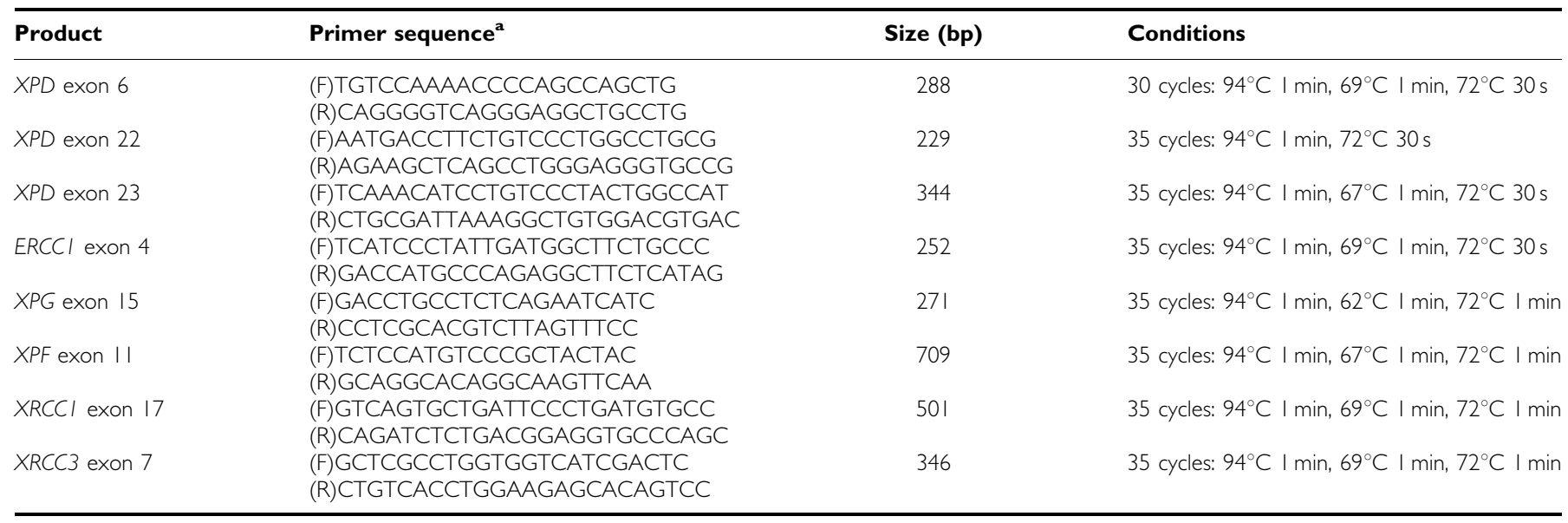

aPrimer sequences were derived from the GenBank entries.

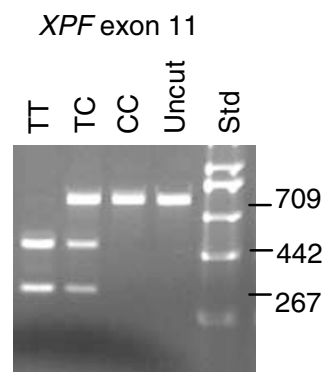

XRCC 1 exon 17

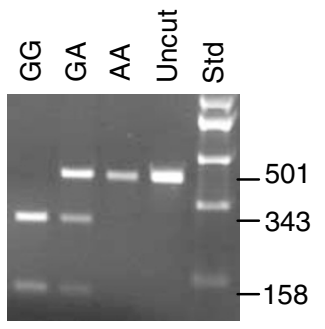

XPG exon 15
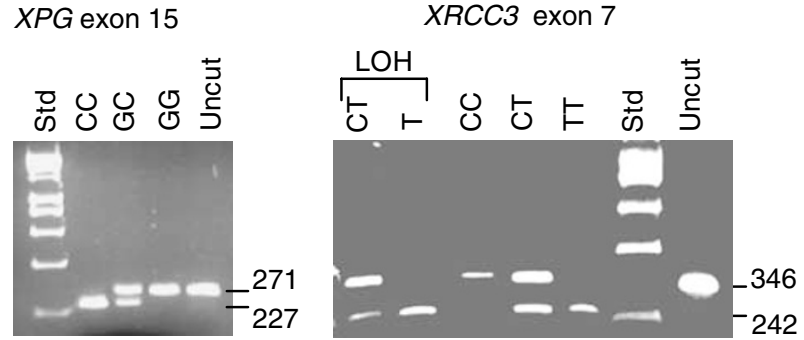

Figure I RFLP analysis of DNA repair gene polymorphisms. The patterns obtained for the polymorphisms in XPF exon II, XRCCI exon 17, $X P G$ exon 15 and XRCC3 exon 7 are indicated. In each case, the sizes (bp) of the fragments generated for each genotype by restriction of the PCR products are shown, along with the uncut PCR product and a molecular size standard (Std). Details of the digests used and fragment sizes are given in Table I. Note that the 44 bp fragment for the XPG assay and the $104 \mathrm{bp}$ fragment for the XRCC3 assay are not resolved on the gels used. For the $X R C C 3$ assay, LOH in a colorectal tumour sample is also shown. Normal tissue from the patient is $C T$, but the tumour is $T$.

\section{Lack of association between NER gene polymorphisms and} colorectal cancer

No significant associations were found between the XPD polymorphisms (exons 6, 22 and 23) and colorectal cancer (Table 3). Similarly, no significant associations were found for $X P F$ exon 11, XPG exon 15 and ERCC1 exon 4 (Table 4).

\section{Association between $X R C C 3$ exon 7 polymorphism and colorectal cancer}

Although no significant association with colorectal cancer was found for the XRCC1 exon 17 polymorphism (Table 5), a
Table 3 Lack of association of XPD polymorphisms and colorectal cancer

\begin{tabular}{|c|c|c|c|c|c|c|}
\hline & \multicolumn{2}{|c|}{$X P D$ exon 6} & \multicolumn{2}{|c|}{$X P D$ exon 22} & \multicolumn{2}{|c|}{$X P D$ exon 23} \\
\hline & A & C & C & $\mathbf{T}$ & $\mathbf{A}$ & C \\
\hline $\begin{array}{l}\text { Patients }{ }^{\mathrm{a}} \\
\text { Controls }^{\mathrm{b}}\end{array}$ & $\begin{array}{r}41 \\
56 \\
\text { OR } 1.2 \\
(95 \% \text { C }\end{array}$ & $\begin{array}{c}49 \\
86 \\
0.43 \\
-2.27)\end{array}$ & \multicolumn{2}{|c|}{$\begin{array}{l}\text { OR 0.94, } P^{c}=0.97 \\
(95 \% \mathrm{Cl} 0.49-1.8 \mathrm{I})\end{array}$} & \multicolumn{2}{|c|}{$\begin{array}{l}\text { OR 0.7I, } P^{c}=0.32 \\
(95 \% \mathrm{Cl} 0.38-1.34)\end{array}$} \\
\hline
\end{tabular}

a Patients: $n=45$. ' Controls: exon 6, $n=71$; exon 22, $n=44$; exon 23, $n=47$. ' $\chi^{2}$ analysis with Yates', correction.

significant association was found for the XRCC3 polymorphism in the first batch of 40 samples genotyped. This association was maintained as the sample size of patient and control groups was increased to over 120, such that the XRCC3 exon $7 \mathrm{C}$ allele was significantly over-represented in the patient group (odds ratio (OR) $1.52,95 \%$ confidence interval (CI) $1.04-2.22, P=0.03$ ).

\section{No LOH at NER gene loci in colorectal cancer}

Where normal tissue biopsied from colorectal cancer patients showed heterozygosity at any of the DNA repair gene loci genotyped, the tumour tissue from the same patients was analysed for LOH. The numbers of heterozygous loci examined in the patients were: 16 for XPD exon 6; 21 for XPD exon 22; 17 for XPD exon 23; 16 for ERCC1 exon 4; 16 for XPF exon 11; 13 for XPG exon 15; 22 for XRCC1 exon 17; 28 for XRCC3 exon 7. From these 149 heterozygous loci examined, only a single example of $\mathrm{LOH}$ was found. This occurred for an XRCC3 exon 7 CT heterozygote where the $\mathrm{C}$ allele was absent in the tumour (Figure 1).

\section{DISCUSSION}

We have investigated the hypothesis that NER gene polymorphisms might predispose to colorectal cancer because some forms of the encoded proteins may be less efficient at repairing DNA damage arising from exposure of the gut epithelium to genotoxic compounds in the lumen. NER is known to be active against a range of bulky DNA lesions in addition to its main role in the repair of UV-induced DNA damage. In a small study, we have previously shown a significant association between melanoma and three polymorphisms in the XPD gene (exon 6 (position 22541) A 
Table 4 Lack of association of NER polymorphisms and colorectal cancer

\begin{tabular}{|c|c|c|c|c|c|c|}
\hline & \multicolumn{2}{|c|}{ XPF exon II } & \multicolumn{2}{|c|}{ XPG exon 15} & \multicolumn{2}{|c|}{$E R C C I$ exon 4} \\
\hline & $\mathbf{T}$ & C & C & G & $\mathbf{G}$ & A \\
\hline $\begin{array}{l}\text { Patients }^{\mathrm{a}} \\
\text { Controls }^{\mathrm{b}}\end{array}$ & \multicolumn{2}{|c|}{$\begin{array}{l}\text { OR } 0.51, P=0.18 \\
(95 \% \mathrm{Cl} 0.19-1.30)\end{array}$} & \multicolumn{2}{|c|}{$\begin{array}{l}\text { OR } 0.51, P=0.13 \\
(95 \% \text { CI } 0.22-1.18)\end{array}$} & $\begin{array}{l}\text { OR I.08, } P=0.87 \\
(95 \% \mathrm{Cl} 0.61-1.92)\end{array}$ & $\begin{array}{r}52 \\
86 \\
0.87 \\
-1.92)\end{array}$ \\
\hline
\end{tabular}

apatients: XPF and XPG, $n=40 ; E R C C 1, n=45 .{ }^{b}$ Controls: $X P F, n=33 ; X P G, n=40$; $E R C C I, n=72$.

Table 5 Association of $X R C C 3$ exon $7 \mathrm{C}$ allele and colorectal cancer

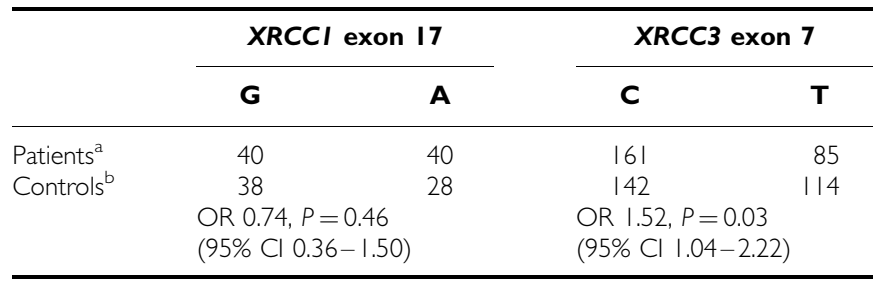

a Patients: $X R C C I, n=40 ; X R C C 3, n=123 .{ }^{b}$ Controls: $X R C C 1, n=33 ; X R C C 3$, $n=128$

allele; exon 22 (position 35326) C allele; exon 23 (position 35931) A allele) that did not extend to markers flanking the XPD gene (Tomescu et al, 2001). A similar association for the XPD exons 6 and 23 polymorphisms has been found in some other, but not all, skin cancer studies (for a review, see Benhamou and Sarasin, 2002). In some studies, the protein encoded by the XPD exon $23 \mathrm{~A}$ allele (Lys $\rightarrow$ Gln change) has been associated with reduced DNA repair activity (for a review, see Benhamou and Sarasin, 2002). The $X P D$ exon 23 polymorphism has also been associated with lung cancer (Chen et $a l, 2002$ ) and an exon 10 polymorphism with SCCHN (Sturgis et al, 2002). A polymorphism in the $3^{\prime}$ UTR of ERCC1 (not the exon 4 RFLP studied here) has been associated with glioma (Chen et al, 2000) and SCCHN (Sturgis et al, 2002) and two XPA polymorphisms are associated with lung cancer (Park et al, 2002). Some of the polymorphisms we have studied lead to a change in the encoded protein (XPD exon 23 Lys-Gln; XPG exon 15 Asp-His; XRCC3 exon 7 Thr-Met), others are silent (XPD exons 6 and 22; XPF exon 11; ERCC1 exon 4; XRCC1 exon 17). A significant association between a protein variant and cancer only indicates that the change might be causative. An association with a silent change indicates that the causative change is closely linked, but remains to be identified. No significant association was found between any of the NER gene polymorphisms studied and colorectal cancer. While this does not exclude the possibility that NER gene polymorphisms might make a minor contribution to genetic predisposition to colorectal cancer, a much larger study than the present one would be required to identify such a minor risk factor.

Similarly, although polymorphisms in exons 6 and 10 of the XRCC1 gene, that is involved in BER and the repair of singlestrand DNA breaks, have been associated with colorectal cancer (reviewed in de Jong et al, 2002) and a range of other internal cancers (Sturgis et al, 1999; Chen et al, 2002; Duell et al, 2002; Stern et al, 2002), no association was seen in our study between the $X R C C 1$ exon 17 polymorphism and colorectal cancer.

A significant association was found for the recombinational repair gene, $X R C C 3$, where the exon $7 \mathrm{C}$ (position 18067, Thr) allele showed a modest (OR 1.52), but significant $(P=0.03)$ overrepresentation in 123 colorectal cancer patients compared to 128 controls. This XRCC3 exon 7 polymorphism has previously shown a significant association with melanoma (Winsey et al, 2000), bladder cancer (Matullo et al, 2001a) and SCCHN (Shen et al, 2002). However, in these studies, it was the variant $T$ (Met) allele that was over-represented in the cancer patients and this allele has also been associated with a reduced DNA repair phenotype (Matullo et al, 2001b).

Conflicting data from association studies between DNA repair gene polymorphisms and cancer susceptibility, or DNA repair capacity, are not unusual (e.g. see Benhamou and Sarasin, 2002, for a review of the XPD data) and many probably result from insufficient sample sizes or inappropriate choice of controls in some studies. However, Nelson et al (2002) have considered how studies on DNA repair gene polymorphisms can produce reliable, but opposite, associations in different types of cancer. The example they considered was the XRCC1 Arg399Gln polymorphism. They suggest that the outcome of a repair variant in a cell may depend on the selection pressures exerted on that cell. If the polymorphism results in reduced repair efficiency, the resultant increased levels of DNA damage may lead to an increased rate of apoptosis. Such a polymorphism would be associated with increased cancer risk in nondividing, or 'apoptosis-abrogated' cells and reduced cancer risk in cells with the capacity for apoptosis. Nelson et al (2002) also highlight that high UV exposure to the skin results in p53 mutant cells which do not apoptose. The variant XRCC3 exon $7 \mathrm{~T}$ allele with reduced repair capacity could result in an increased cancer risk in the skin (by the fixation of mutations in p53 mutant cells) and a protective effect in the gut (by more efficient apoptosis).

The mechanism for the reduced repair capacity associated with the variant $X R C C 3$ exon $7 \mathrm{~T}$ allele is unknown. It may alter the protein's interaction with RAD51, but could also affect other aspects of the role of XRCC3. This highlights the main difficulty with studies designed to look at single polymorphisms without knowledge of their functional significance. Without detailed knowledge of XRCC3's roles in DNA repair, it is hard to evaluate the significance of such studies, or exclude a role for confounding factors. In the same way as we have done for XPD and melanoma (Tomescu et al, 2001), study of XRCC3 flanking markers will be required to rule out roles for linkage disequilibrium and population stratification in the association found.

Our study suggested that LOH of NER genes and XRCC1 and $X R C C 3$ does not play an important role in colorectal carcinogenesis. Indeed, only a single example of $\mathrm{LOH}$ was found (for XRCC3) in 149 heterozygous loci examined. In addition to reporting a high rate of LOH for NER genes in ovarian and lung cancer, Takebayashi et al (2001) reported LOH for NER genes in $16.7 \%$ of colon carcinomas. Closer examination of their data reveals that this equates to $\mathrm{LOH}$ for $X P E$ in a single patient and $\mathrm{LOH}$ for $X P B$ and $X P E$ in a second patient, from a total of 12 patients examined and eight NER genes typed (44 out of 96 assays were noninformative). Thus, the two studies are in agreement that the frequency of LOH for NER genes is low in colorectal cancer.

In conclusion, association and LOH studies suggest that NER genes are not important genetic determinants for colorectal carcinogenesis. A modest association between colorectal cancer and a polymorphism in the recombination repair gene XRCC3 was found, but additional studies will be required to evaluate its importance.

\section{ACKNOWLEDGEMENT}

This study was supported by a programme grant (SP2095/0301) from Cancer Research UK to DWM. 


\section{REFERENCES}

Benhamou S, Sarasin A (2002) ERCC2/XPD gene polymorphisms and cancer risk. Mutagenesis 17: 463-469

Berwick M, Vineis P (2000) Markers of DNA repair and susceptibility to cancer in humans: an epidemiologic review. J Natl Cancer Inst 92: 874-897

Chen P, Wiencke J, Aldape K, Kesler-Diaz A, Miike R, Kelsey K, Lee M, Liu J, Wrensch M (2000) Association of an ERCC1 polymorphism with adultonset glioma. Cancer Epidemiol Biomarkers Prev 9: 843 - 847

Chen S, Tang D, Xue K, Xu L, Ma G, Hsu Y, Cho SS (2002) DNA repair gene $X R C C 1$ and $X P D$ polymorphisms and risk of lung cancer in a Chinese population. Carcinogenesis 23: $1321-1325$

de Jong MM, Nolte IM, te Meerman GJ, van der Graaf WTA, de Vries EGE, Sijmons RH, Hofstra RMW, Kleibeuker JH (2002) Low-penetrance genes and their involvement in colorectal cancer susceptibility. Cancer Epidemiol Biomarkers Prev 11: $1332-1352$

Duell EJ, Holly EA, Bracci PM, Wiencke JK, Kelsey KT (2002) A populationbased study of the Arg399Gln polymorphism in X-ray repair crosscomplementing group 1 (XRCC1) and risk of pancreatic adenocarcinoma. Cancer Res 62: 4630-4636

Emmert S, Schneider TD, Khan SG, Kraemer KH (2001) The human XPG gene: gene architecture, alternative splicing and single nucleotide polymorphisms. Nucleic Acids Res 29: 1443-1452

Friedberg EC (2001) How nucleotide excision repair protects against cancer. Nat Rev Cancer 1: $22-33$

Friedberg EC, Walker GC, Siede W (1995) DNA Repair and Mutagenesis. ASM Press: Washington, DC

Griffin CS, Simpson PJ, Wilson CR, Thacker J (2000) Mammalian recombination-repair genes $X R C C 2$ and $X R C C 3$ promote correct chromosome segregation. Nat Cell Biol 2: 757-761

Jiricny J, Nystrom-Lahti M (2000) Mismatch repair defects in cancer. Curr Opin Genet Dev 10: $157-161$

Lunn RM, Helzlsouer KJ, Parshad R, Umbach DM, Harris EL, Sanford KK, Bell DA (2000) XPD polymorphisms: effects on DNA repair proficiency. Carcinogenesis 21: $551-555$

Matullo G, Guarrera S, Carturan S, Peluso M, Malaveille C, Davico L, Piazza A, Vineis P (2001a) DNA repair gene polymorphisms, bulky DNA adducts in white blood cells and bladder cancer in a case - control study. Int J Cancer 92: 562-567

Matullo G, Palli D, Peluso M, Guarrera S, Carturan S, Celentano E, Krogh V, Munnia A, Tumino R, Polidoro S, Piazza A, Vineis P (2001b) XRCC1, $X R C C 3, X P D$ gene polymorphisms, smoking and ${ }^{32} \mathrm{P}$-DNA adducts in a sample of healthy subjects. Carcinogenesis 22: 1437-1445

Nelson HH, Kelsey KT, Mott LA, Karagas MR (2002) The XRCC1 Arg399Gln polymorphism, sunburn and non-melanoma skin cancer: evidence of gene-environment interaction. Cancer Res 62: 152-155
Park JY, Park SH, Choi JE, Lee SY, Jeon HS, Cha SI, Kim CH, Park JH, Kam S, Park RW, Kim IS, Jung TH (2002) Polymorphisms of the DNA repair gene xeroderma pigmentosum group $\mathrm{A}$ and risk of primary lung cancer. Cancer Epidemiol Biomarkers Prev 11: 993-997

Qiao Y, Spitz MR, Guo Z, Hadeyati M, Grossman L, Kraemer KH, Wei Q (2002) Rapid assessment of repair of ultraviolet DNA damage with a modified host-cell reactivation assay using a luciferase reporter gene and correlation with polymorphisms of DNA repair genes in normal human lymphocytes. Mutat Res 509: 165-174

Shen MR, Jones IM, Mohrenweiser H (1998) Nonconservative amino acid substitution variants exist at polymorphic frequency in DNA repair genes in healthy humans. Cancer Res 58: 604-608

Shen H, Sturgis EM, Dahlstrom KR, Zheng Y, Spitz MR, Wei Q (2002) A variant of the DNA repair gene XRCC3 and risk of squamous cell carcinoma of the head and neck: a case - control analysis. Int J Cancer 99: $869-872$

Stern MC, Umbach DM, Lunn RM, Taylor JA (2002) DNA repair gene XRCC3 codon 241 polymorphism, its interaction with smoking and XRCC1 polymorphisms, and bladder cancer risk. Cancer Epidemiol Biomarkers Prev 11: 939-943

Sturgis EM, Castillo EJ, Li L, Zheng R, Eicher SA, Clayman GL, Strom SS, Spitz MR, Wei Q (1999) Polymorphisms of DNA repair gene XRCC1 in squamous cell carcinoma of the head and neck. Carcinogenesis 20: $2125-2129$

Sturgis EM, Dahlstrom KR, Spitz MR, Wei Q (2002) DNA repair gene ERCC1 and ERCC2/XPD polymorphisms and risk of squamous cell carcinoma of the head and neck. Arch Otolaryngol Head Neck Surg 128: $1084-1088$

Takebayashi Y, Nakayama K, Kanzaki A, Miyashita H, Ogura O, Mori S, Mutoh M, Miyazaki K, Fukumoto M, Pommier Y (2001) Loss of heterozygosity of nucleotide excision repair factors in sporadic ovarian, colon and lung carcinomas: implication for their roles of carcinogenesis in human solid tumours. Cancer Lett 174: $115-125$

Tomescu D, Kavanagh G, Ha T, Campbell H, Melton D (2001) Nucleotide excision repair gene $X P D$ polymorphisms and genetic predisposition to melanoma. Carcinogenesis 22: 403-408

Winsey SL, Haldar NA, Marsh HP, Bunce M, Marshall SE, Harris AL, Wojnarowska F, Welsh KI (2000) A variant of the DNA repair gene $X R C C 3$ is associated with the development of melanoma skin cancer. Cancer Res 60: 5612-5616

Wood RD (1997) Nucleotide excision repair in mammalian cells. J Biol Chem 272: 23465-23468 